\title{
Transduction for Pheromones in the Main Olfactory Epithelium Is Mediated by the $\mathrm{Ca}^{2+}$-Activated Channel TRPM5
}

\author{
Fabián López, ${ }^{1}$ Ricardo Delgado, ${ }^{1}$ Roberto López, ${ }^{2}$ Juan Bacigalupo, ${ }^{1 *}$ and Diego Restrepo ${ }^{2 *}$ \\ ${ }^{1}$ Department of Biology, Faculty of Sciences, University of Chile, Santiago 1058, Chile, ${ }^{2}$ Department of Cell and Developmental Biology, Neuroscience \\ Program, and Rocky Mountain Taste and Smell Center, Anschutz Medical Campus, University of Colorado, Aurora, Colorado 80045
}

Growing evidence suggests that the main olfactory epithelium contains a subset of olfactory sensory neurons (OSNs) responding to pheromones. One candidate subpopulation expresses the calcium activated cation channel TRPM5 (transient receptor potential channel M5). Using GFP driven by the TRPM5 promoter in mice, we show that this subpopulation responds to putative pheromones, urine, and major histocompatibility complex peptides, but not to regular odors or a pheromone detected by other species. In addition, this subpopulation of TRPM5-GFP ${ }^{+}$OSNs uses novel transduction. In regular OSNs, odorants elicit activation of the cyclic nucleotide-gated (CNG) channel, leading to $\mathrm{Ca}^{2+}$ gating of $\mathrm{Cl}^{-}$channels; in TRPM5-GFP ${ }^{+}$OSNs, the $\mathrm{Ca}^{2+}$-activated $\mathrm{Cl}^{-}$ANO2 (anoctamin 2 ) channel is not expressed, and pheromones elicit activation of the CNG channel leading to $\mathrm{Ca}^{2+}$ gating of TRPM5. In conclusion, we show that OSNs expressing TRPM5 respond to pheromones, but not to regular odors through the opening of $\mathrm{CNG}$ channels leading to $\mathrm{Ca}^{2+}$ gating of TRPM5.

Key words: olfactory; pheromone; transduction; TRPM5

\section{Introduction}

Most mammals, with the notable exception of higher primates (Finger et al., 2000; Wysocki and Preti, 2004; Trotier, 2011; Baum, 2012), possess two separate chemosensory tissues within their nasal cavity, the main olfactory epithelium (MOE) and the vomeronasal organ (VNO). The predominant view was that the MOE is responsible for detecting volatile environmental odorants, while the VNO, which is absent in higher primates (Wysocki and Preti, 2004; Trotier, 2011), senses pheromones (Dulac and Torello, 2003; Halpern and Martínez-Marcos, 2003). Yet, recent data suggest that an uncharacterized subpopulation of specialized olfactory sensory neurons (OSNs) in the mouse MOE also contributes to the detection of volatile pheromones with an unknown transduction mechanism (Wang et al., 2007; Zufall and Leinders-Zufall, 2007; Tirindelli et al., 2009; Baum, 2012).

Transduction in OSNs is fairly well understood. Odorants bind to receptors present in the cilia, triggering the activation of

Received Nov. 21, 2013; revised Jan. 10, 2014; accepted Jan. 16, 2014.

Author contributions: F.L., J.B., and D.R. designed research; F.L., R.D., R.L., and D.R. performed research; F.L. and D.R. analyzed data; F.L., J.B., and D.R. wrote the paper.

This research was supported by MIDEPLAN Grant ICM-P05-001 (J.B.); and Fondo Nacional de Desarrollo Científico y Tecnológico (FONDECYT) Grants 1100682 (J.B.), DC04657 (D.R.), DC006070 (D.R.), and TW007920 (J.B. and D.R.). We thank Baris 0zbay for help with $\mathrm{Ca}^{2+}$ imaging and Nicole Arevalo for technical support.

*J.B. and D.R. contributed equally to this work as senior authors.

The authors declare no competing financial interests.

Correspondence should be addressed to Dr. Diego Restrepo, University of Colorado Denver, Department of Cell and Developmental Biology, Building RC1 South, Room L18-11119, 12801 East 17th Avenue, Aurora, C0 80045. E-mail: diego.restrepo@ucdenver.edu.

DOI:10.1523/JNEUROSCI.4903-13.2014

Copyright $\odot 2014$ the authors $\quad 0270-6474 / 14 / 343268-11 \$ 15.00 / 0$ adenylyl cyclase III (Bakalyar and Reed, 1990), mediated by the G-protein termed $\mathrm{G}_{\text {olf }}$ (Jones and Reed, 1989). The cyclase generates cAMP, which directly opens an unselective cationic cyclic nucleotide-gated (CNG) channel mediating a $\mathrm{Ca}^{2+}$ influx $(\mathrm{Na}-$ kamura and Gold, 1987; Baker et al., 1999). $\mathrm{Ca}^{2+}$ in turn gates a $\mathrm{Ca}^{2+}$-activated $\mathrm{Cl}^{-}$channel (Kleene and Gesteland, 1991; Lowe and Gold, 1993), suggested to be ANO2 (anoctamin 2; Stephan et al., 2009; Stöhr et al., 2009; Rasche et al., 2010; for review, see Schild and Restrepo, 1998; Munger et al., 2009; Ma, 2012). The electrochemical gradient for $\mathrm{Cl}^{-}$in the cilia favors an efflux of this anion through the $\mathrm{Ca}^{2+}$-activated $\mathrm{Cl}^{-}$channel, which significantly potentiates the depolarizing effect of the CNG channel (Kurahashi and Yau, 1993; Lowe and Gold, 1993; but see Billig et al., 2011).

In contrast, transduction for pheromones in the MOE is poorly understood (Munger et al., 2009; Baum, 2012). Immunohistochemical data have shown that a subset of OSNs express TRPM5 (transient receptor potential channel M5) in the cilia (Kaske et al., 2007; Lin et al., 2007), and because CNG channel subunit A2 (CNGA2) is likely expressed in these cilia (Lin et al., 2007), these studies suggested, but did not prove, that TRPM5 could be activated by $\mathrm{Ca}^{2+}$ influx through CNGA2 and be involved in pheromone transduction in the MOE. In addition, indirect evidence showing differential inhibition by pharmacological block of adenylyl cyclase III of the electroolfactogram (EOG) response of two putative pheromones 2-heptanaone and 2,5-dimethylpyrazine (DMP) versus two general odorants in controls but not in TRPM5 knockouts suggests that TRPM5 is involved in the transduction of pheromonal responses (Lin et al., 
2007). Finally, recent work indicated that TRPM5 likely plays a role in mediating transduction for putative pheromones (Oshimoto et al., 2013). However, EOGs for pheromones were not significantly altered in TRPM5 knockouts (Lin et al., 2007), raising the question of whether TRPM5 is involved in transduction of responses to pheromones. Here, we hypothesized that pheromonal responses of OSNs expressing TRPM5 are mediated by $\mathrm{Ca}^{2+}$ influx through CNGA2 activating TRPM5 to eliciting depolarization, and this hypothesis was directly tested thorough profiling of transduction in this subpopulation of cells using electrophysiological recording and $\mathrm{Ca}^{2+}$ imaging.

\section{Materials and Methods}

Animals. TRPM5-GFP mice (Clapp et al., 2006) were kept as a homozygous colony bred back regularly to C57BL/6. TRPM5 knock-out (KO) mice (Damak et al., 2006) were bred with TRPM5-GFP mice to obtain TRPM5-KO-GFP mice, which express GFP in OSNs that would have expressed TRPM5. These mice were bred back on the average of every 6 months to C57BL/6. GFP is used to identify cells that express fluorescence under the control of the TRPM5 promoter in either wild-type or TRPM5 knock-out mice. Mice were kept in the National Institutes of Health-approved animal facility of the University of Colorado Anschutz Medical Center, or at the animal facility of the University of Chile and were used at $2-8$ months old. They were given food and water ad libitum, and were maintained in a $12 \mathrm{~h}$ light/dark cycle. All procedures were in compliance with the University of Colorado Anschutz Medical Campus Institutional Animal Care and Use Committee (IACUC). In experiments, we used mostly female mice $(\sim 80 \%)$. Future studies should characterize the responses of OSNs expressing TRPM5 in female versus male mice because female mice have been shown to respond differentially to male volatile pheromones (Kang et al., 2009).

Isolated OSNs. The animals were killed by overdose of $\mathrm{CO}_{2}$ inhalation, a method approved by the University of Colorado Anschutz Medical Campus IACUC. The olfactory epithelium was removed from the nasal cavity, and OSNs were isolated by mechanical dissociation (Sanhueza et al., 2000; Schmachtenberg et al., 2003). TRPM5 GFP ${ }^{+}$and TRPM5 $\mathrm{GFP}^{-}$neurons were separated by differential intensity of fluorescence emitted in the green channel.

Solutions for loose-patch and $\mathrm{Ca}^{2+}$ imaging. The composition of the solutions used in this study was as follows (in $\mathrm{mm}$ ): normal Ringer's solution: $145 \mathrm{NaCl}, 5 \mathrm{KCl}, 10 \mathrm{HEPES}, 1 \mathrm{MgCl}_{2}, 1 \mathrm{CaCl}_{2}, 1 \mathrm{Na}$-pyruvate, and 5 D-glucose, $\mathrm{pH}$ 7.4; high $\mathrm{Ca}^{2+}$ Ringer's (used in the $\mathrm{Ca}^{2+}$ imaging experiments): $145 \mathrm{NaCl}, 5 \mathrm{KCl}, 10$ HEPES, $1 \mathrm{MgCl}_{2}, 3 \mathrm{CaCl}_{2}, 1 \mathrm{Na}-$ pyruvate, and $5 \mathrm{D}$-glucose, pH 7.4; and 0-Ca ${ }^{2+}$ Ringer's: $145 \mathrm{NaCl}, 5 \mathrm{KCl}$, 10 HEPES, 1 EGTA, $3 \mathrm{MgCl}_{2}$, 1 Na-pyruvate, and 5 D-glucose, $\mathrm{pH}$ 7.4.

Odorants, pheromones, and other chemicals. Odorants and pheromones were obtained from Aldrich Chemical Company. Odorants and pheromones were freshly diluted into normal Ringer's solution, vortexed vigorously, and sonicated. We used three chemicals reported to be male mouse pheromones (2-heptanone, DMP, and E- $\beta$-farnesene; Novotny et al., 1990; Leinders-Zufall et al., 2000; Wang et al., 2007; Zufall and Leinders-Zufall, 2007) and a male pig pheromone (androstenone; Dorries et al., 1995), or a blend of odorants (citralva, isoamyl acetate, lilial, cineol, pine, and black pepper). Urine was obtained from adult (2- to 5-month-old) male or female C57BL/6 mice that had not been exposed to the other sex. Major histocompatibility complex (MHC) peptides AAPDNRETF and ANPRAFDTE (Spehr et al., 2006a) were generated and purified by HPLC by the Peptide and Protein Chemistry Core of the University of Colorado Anschutz Medical Campus. The TRPM5 inhibitor triphenylphosphine oxide (TPPO) was purchased from Aldrich Chemical Company, the ANO2 inhibitor niflumic acid was from Sigma, and the CNG channel inhibitor L-cis-diltiazem hydrochloride was from Abcam. The rest of the chemicals were purchased from Sigma-Aldrich.

Immunohistochemistry. The isolated OSNs were allowed to settle on Shandon CytoSpin coated microscope slides (Thermo Scientific) for 30 min. The slides had been pretreated with $1 \mathrm{mg} / \mathrm{ml}$ concanavalin A and 1 $\mathrm{mg} / \mathrm{ml}$ poly-L-lysine hydrobromide (Aldrich Chemical Company). OSNs were fixed with $4 \%$ paraformaldehyde in $\mathrm{PBS}\left(28.75 \mathrm{~mm} \mathrm{NaH}_{2} \mathrm{PO}_{4}, 75 \mathrm{~mm}\right.$
$\mathrm{Na}_{2} \mathrm{HPO}_{4}$ ), pH 7.2, for $20 \mathrm{~min}$. Cells were washed in $0.1 \mathrm{M}$ PBS, blocked in blocking solution containing $1 \%$ BSA, 3\% normal donkey serum, and $0.3 \%$ Triton X-100 in PBS for $2 \mathrm{~h}$. Isolated OSNs were then immunoreacted overnight in the cold room with primary antibodies against the following proteins: rabbit IgG against ANO2 (1:1000; Billig et al., 2011) and goat IgG against CNGA2 (1:500; Santa Cruz Biotechnology). Isolated OSNs were then washed and reacted with donkey anti-rabbit secondary antibody (1:400; Alexa Fluor 568, Invitrogen) or donkey antigoat secondary antibody (1:400; Alexa Fluor 568, Invitrogen). In controls for these experiments, (1) primary antibodies were removed, resulting in negative labeling, and (2) the antibodies labeled the cilia of olfactory epithelium slices but did not label the respiratory epithelium (see Fig. 3).

Confocal images of immunolabeled OSNs were captured using an Olympus Fluoview confocal laser-scanning microscope (LSCM) FV300 (Olympus) using an oil-immersion $60 \times$ objective Olympus PlanApo [1.4 numerical aperture (NA)]. To avoid any problems resulting from side-band excitation of the fluorochromes, channels in each image were collected sequentially with single-wavelength excitation and then were merged to produce the composite image using Fluoview version 5.0 software. Brightness and contrast were adjusted in Adobe Photoshop. The figures for the isolated cells were deconvolved in MATLAB using the Richardson-Lucy deconvolution method (Gonzalez-Silva et al., 2013).

Loose-patch electrophysiology. Cells were viewed in an Olympus IX70 inverted microscope, with a $40 \times / 0.65 \mathrm{Ph} 2 \mathrm{DL}$ objective Nikon Plan. We used an Axopatch 1D patch-clamp amplifier (Molecular Devices) for recording extracellular currents in the loose-patch modality (Reisert and Matthews (2001). The pClamp 6 software (Molecular Devices) was used for data acquisition and analysis. The patch pipettes were made of soft glass capillaries (Bris, Globe Scientific) for tip diameters of 2-4 M $\Omega$ of resistance. To deliver odors in the experiments with odorants, we used Theta glass pipettes (Sutter Instrument) with tip diameters of $\sim 1 \mu \mathrm{m}$ each; the pipettes were positioned $\sim 10 \mu \mathrm{m}$ from the cilia. A custommade computer-operated Picospritzer controlled the solution flow from the barrels. A dilution factor for stimuli delivered from the pipette to the cell of $8 \pm 0.7(n=3)$ was determined using the procedure of Firestein and Werblin (1989). Concentrations in Figures 1 and 2 were converted by dividing by the dilution factor.

Inside-out excised patch recordings. Borosilicate glass pipettes of $40 \mathrm{M} \Omega$ resistance were sealed on the base of individual cilia of TRPM5-GFP ${ }^{+}$ OSNs. The currents were acquired at $10 \mathrm{kHz}$ and low pass filtered at 2 $\mathrm{kHz}$ (8-pole Bessel filter). The baseline drift of the current records was digitally corrected and filtered to $500 \mathrm{~Hz}$ for analysis using pClamp 10 software (Molecular Devices). The pipette was filled with a solution containing the following (in mM): $110 \mathrm{~N}$-methyl D-glucamine (NMDG)-Cl (Sigma), $5 \mathrm{NaCl}, \mathrm{CaCl}_{2}$, EGTA, yielding $100 \mu \mathrm{M}$ free $\mathrm{Ca}^{2+}, 10 \mathrm{HEPES}$, $\mathrm{pH} 7.6$ (extracellular medium). The cytoplasmic side was bathed with a puffer pipette containing the following (in mM): $110 \mathrm{NaCl}, 10 \mathrm{HEPES}$, and different concentrations of $\mathrm{Ca}^{2+}$ /HEDTA yielding free $\mathrm{Ca}^{2+}$ ranging from 1.2 to $50 \mu \mathrm{M}, \mathrm{pH}$ 7.6. In the experiment using cAMP, the cytoplasmic solution was as follows (in mM): 10 NMDG-Cl, 110 NMDGacetate, $5 \mathrm{NaCl}, 8 \mu \mathrm{M}$ free- $\mathrm{Ca}^{2+}$, $\mathrm{pH} 7.6$, and 10 HEPES. TPPO, niflumic acid, and cAMP were supplemented with the corresponding cytoplasmic solutions before adjusting the $\mathrm{pH}$.

Calcium imaging. Cells were preincubated at room temperature for 30 min in Ringer's solution supplemented with $1 \mu \mathrm{m} \mathrm{X-rhod-1} \mathrm{acetoxym-}$ ethyl ester probe and 20\% pluronic acid F-127 (Invitrogen), and then washed several times with high $\mathrm{Ca}^{2+}$ Ringer's solution. Isolated OSNs were imaged using a water-immersion $60 \times$ objective Olympus LUMPlanFL/IR (0.9 NA) in the red channel of the Olympus Fluoview confocal LSCM FV300 (Olympus). Cilia segments of $\sim 1 \mu \mathrm{m}$ were chosen for $\mathrm{Ca}^{2+}$-dependent fluorescence measurements in line-scan mode. Cilia were scanned every $\sim 2 \mathrm{~ms}$ (range, $1.6-2.2 \mathrm{~ms}$ ) for $1 \mathrm{~min}$, providing a measurement of $\mathrm{Ca}^{2+}$-dependent fluorescence changes as a function of time and distance in the ciliary segment. Time resolution was similar, but not identical, throughout the experiments, because it depended on the length of the segment examined. To test the possibility that transient fluorescence events could be artifacts of nonbiological origin, we performed the following controls: (1) we compared line-scan fluorescence measurements of OSNs performed in high $\mathrm{Ca}^{2+}$ Ringer's solution and 
A

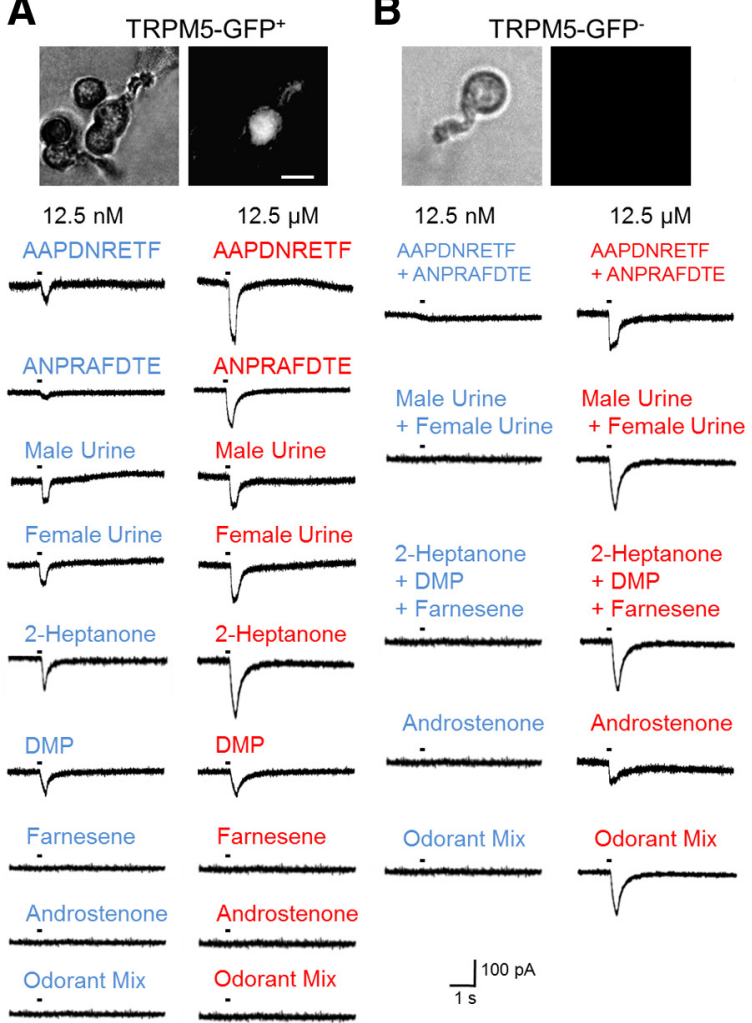

C

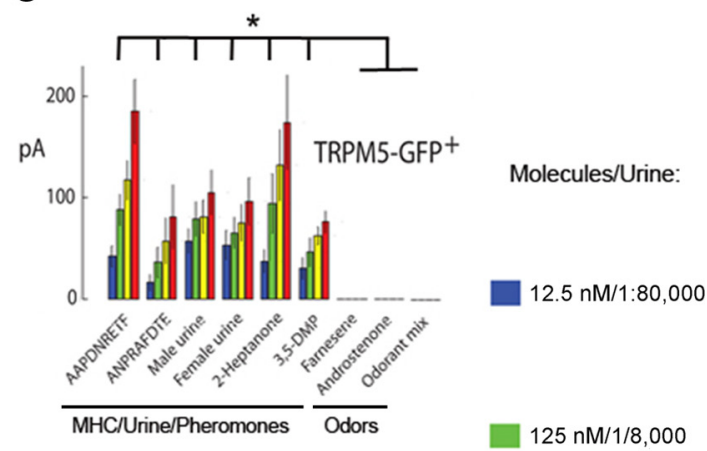

D

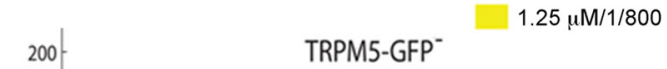

$12.5 \mu \mathrm{M} / 1 / 80$

Figure 1. Chemosensory neurons expressing GFP in TRPM5-GFP mice respond to MHC peptides, two pheromones, and urine, but not to general odorants and E- $\beta$-farnesene. $A, B$, Photographs of the TRPM5-GFP ${ }^{+}\left(\boldsymbol{A}\right.$, top) or TRPM5-GFP- ${ }^{-}\left(\boldsymbol{B}\right.$, top) 0SNs under phase contrast (left) and fluorescence (right) optics, and results of loose-patch current recordings from TRPM5-GFP ${ }^{+}(\boldsymbol{A})$ or TRPM5-GFP $^{-}(\boldsymbol{B})$ OSNs stimulated with 200 ms puffs of pheromones, MHC peptides, urine, or odorants. $\boldsymbol{C}, \boldsymbol{D}$, Average peak currents ( \pm SEM) of the responses induced by stimuli at different concentrations in TRPM5-GFP ${ }^{+}(C)$ or TRPM5-GFP ${ }^{-}$(D) OSNs. The number of OSNs responding to each odor were as follows: TRPM5-GFP ${ }^{+}$: AAPDNRETF (5 of 14), ANPRAFDTE (3 of 30), male C57BL/ 6 urine (7 of 18), female (57BL/ 6 urine (7 of 18), 2 -heptanone (5 of 18), DMP (5 of 15), E- $\beta$-farnesene ( 0 of 15$)$, androstenone ( 0 of 15$)$, and odorant mixture (citralva, isoamyl acetate, lilial, cineol, pine, and black pepper; 0 of 20); TRPM5-GFP- ${ }^{-}$mixture of AAPDNRETF and ANPRAFDTE ( 6 of 17), mixture of male and female (57BL/ 6 urine ( 8 of 20), mixture of 2-heptanone, DMP, and $\mathrm{E}-\beta$-farnesene (10 of 26), androstenone ( 5 of 20), and odorant mixture (7 of 17). The asterisk denotes significant differences in responses to the highest concentration of the stimulus determined using the Wilcoxon rank sum tets, $p<0.0025$ with the $p$ value corrected by false discovery rate $(p<0.03)$. Odor concentrations for $\boldsymbol{D}$ were as follows: $12.5 \mathrm{~nm}, 125 \mathrm{~nm}, 1.25 \mu \mathrm{M}$, and $12.5 \mu \mathrm{m}$, except for the urine, which was diluted 1:80, 1:800, 1:8000, and 1:80,000. Error bars indicate SEM.

0- $\mathrm{Ca}^{2+}$ Ringer's solution (see Fig. 6); (2) pheromone-induced fluorescence changes in TRPM5-GFP ${ }^{+}$OSNs were inhibited by the CNG inhibitor L-cis-diltiazem (see Fig. 5); and (3) we performed line-scan fluorescence measurements in an external solution containing the fluorophore (in its cell-impermeant form) at a concentration of $1 \mu \mathrm{M}$, resulting in emission of light with intensities in the same range as the fluorescence measured from the cells. These measurements gave a rather uniform fluorescence signal, completely devoid of transient events. These data strongly support the biological origin of the transient fluorescence signals recorded from the cilia.

Cilia diameter decreases with distance from the knob (Menco, 1997), and therefore, at the beginning of the measurement fluorescence, decreased with distance from the knob. Because of this, fluorescence for X-rhod-1 was normalized by dividing fluorescence intensity by a straight-line fit of fluorescence intensity as a function of distance for the period preceding stimulation. To improve the signal-to-noise ratio, the signal in the ciliary segment was averaged in $0.24 \mu \mathrm{m}$ windows and the corresponding line-scan fluorescence measurements were averaged in $0.2 \mathrm{~s}$ time windows.

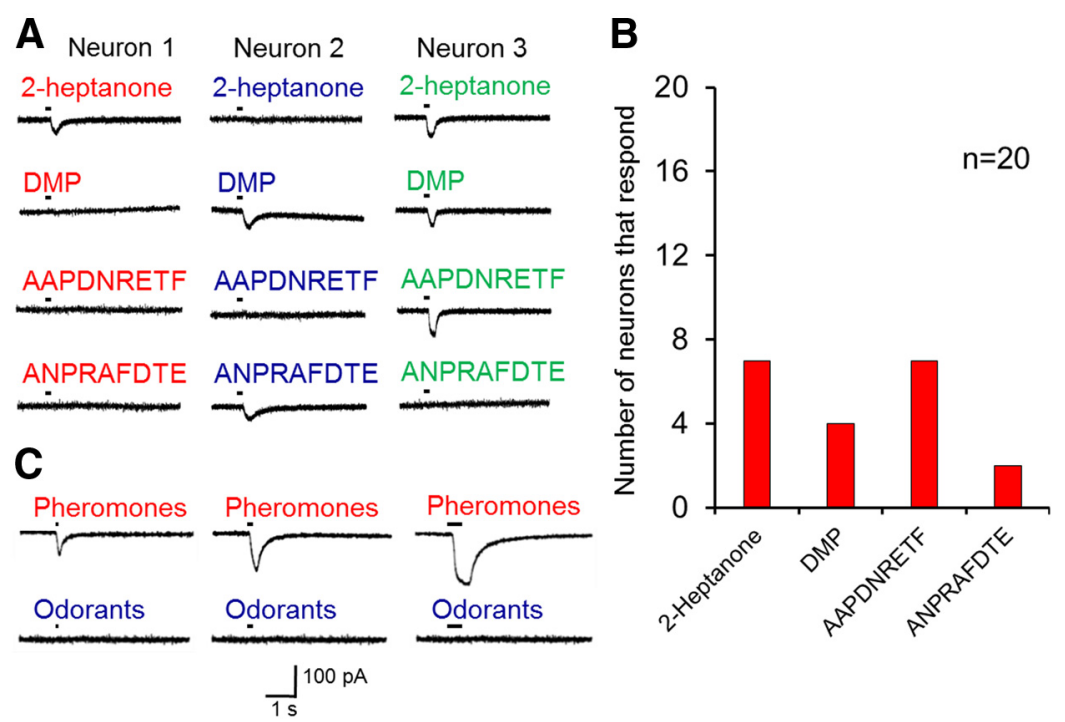

Figure 2. Results of loose-patch experiments where TRPM5-GFP ${ }^{+}$OSNs were stimulated with puffs of $200 \mathrm{~ms}$ duration with $12.5 \mathrm{~nm}$ 2-heptanone, DMP, and MHC peptides. As shown in $\boldsymbol{A}$, some 0SNs responded to one of these compounds, while others responded to several of the stimuli. $\boldsymbol{B}$, Shows the percentage of neurons responding to each of these stimuli. Of the $200 \mathrm{SNs}, 10 \mathrm{did}$ not respond to any of the stimuli, 3 responded to one stimulus, 3 responded to two stimuli, and 4 responded to three stimuli. $C$, Loose-patch current recordings from a TRPM5-GFP ${ }^{+}$OSN stimulated with pheromones (12.5 $\mu \mathrm{M}$ 2-heptanone and DMP) or odorants (12.5 $\mu \mathrm{m}$ isoamyl acetate, cineole, citralve, and limonene) with puffs of different durations (100, 200, and $500 \mathrm{~ms})$. 
Fluorescence as a function of time ( $\mathrm{F}$ ) was normalized to 1 by dividing $\mathrm{F}$ by the "basal" fluorescence measured for a $0.5 \mathrm{~s}$ interval immediately preceding stimulation $(\mathrm{Fi})$.

Statistics. Because measures in electrophysiology and calcium imaging experiments were not distributed normally (Kolmogorov-Smirnov test), we used a Wilcoxon rank sum test to determine the statistical significance between the changes in each of these parameters (Ding and Wilkins, 2004). A $\chi^{2}$ test was used to determine whether the number of responsive cells differed between treatments. The level of significance was $p<0.05$, and if necessary the $p$ value was corrected for multiple comparisons using false discovery rate (FDR; Curran-Everett, 2000). Matlab R2012 (MathWorks) was used to perform statistical tests.

\section{Results}

GFP-expressing olfactory sensory neurons in TRPM5-GFP mice are specifically responsive to low concentrations of pheromones, urine, and MHC peptides

To determine whether green fluorescent cells (TRPM5-GFP ${ }^{+}$) responded to pheromones or odors, we conducted loose-patch current recordings from dissociated OSNs stimulated with mouse pheromones using puffer pipettes containing $100 \mathrm{~nm}$ to $100 \mu \mathrm{M}$ 2-heptanone, 2,5-dimethylpyrazine, DMP, or E- $\beta$ farnesene (Novotny et al., 1990; Leinders-Zufall et al., 2000; Wang et al., 2007; Zufall and Leinders-Zufall, 2007), 1:10,000 to $1: 10$ dilution of male and female C57BL/ 6 mouse urine, $100 \mathrm{~nm}$ to $100 \mu \mathrm{M}$ androstenone (a pheromone for pig, but not for mice; Dorries et al., 1995), $100 \mathrm{~nm}$ to $100 \mu \mathrm{M}$ MHC peptide detected at low concentration (AAPDNRETF) and another detected at high concentration (ANPRAFDTE) by mouse OSNs (Spehr et al., 2006a), or a blend of odorants (100 nM to $100 \mu \mathrm{M}$ citralva, isoamyl acetate, lilial, cineol, pine, and black pepper). In our experiments, the effective concentration of these compounds at the cilia were eightfold lower, due to the measured dilution factor (see Materials and Methods), thus we will refer from here on to the effective values.

Figure 1, $A$ and $B$, shows loose-patch responses with these compounds in two representative OSNs (Fig. 1A, TRPM5-GFP ${ }^{+}$, $B$, TRPM5-GFP ${ }^{-}$), and Figure $1, C$ and $D$, displays the average loose-patch responses of TRPM5-GFP ${ }^{+}$and TRPM5-GFP OSNs, respectively. Interestingly, two of the pheromones (2heptanone and DMP), the two MHC peptides, and urine elicited responses at low concentrations (12.5 $\mathrm{nm}$ and 1:80,000 dilution) in TRPM5-GFP ${ }^{+}$neurons, but none of them responded to odorant mixtures, androstenone, and $\mathrm{E}-\beta$-farnesene (Fig. 1C). In sharp contrast, Figure $1 D$ shows that all stimuli activated TRPM5-GFP ${ }^{-}$OSNs at concentrations at or above $125 \mathrm{nM}$, but none responded at the lowest concentration (12.5 nM). In separate complementary experiments, a subset of TRPM5-GFP ${ }^{+}$ OSNs stimulated with $12.5 \mathrm{~nm}$ 2-heptanone, DMP, or MHC peptides responded to one to three of the compounds (Fig. 2). The rest of those cells were nonresponsive.

These results show that the TRPM5-expressing cells of the MOE are specialized to a subset of the pheromones, urine, and MHC peptides tested here, while the TRPM5-GFP ${ }^{-}$neurons can respond to environmental odorants as well as all pheromones. Importantly, the specialized TRPM5-expressing cells were considerably more sensitive to pheromones than the neurons that did not express this channel.

OSNs expressing GFP in TRPM5-GFP mice express in the cilia CNGA2, but not ANO2

In a previous study (Lin et al., 2007) of cryosections of the olfactory epithelium of TRPM5-GFP mice, CNGA2 was expressed in the soma of the subset of OSNs expressing GFP, suggesting coex-
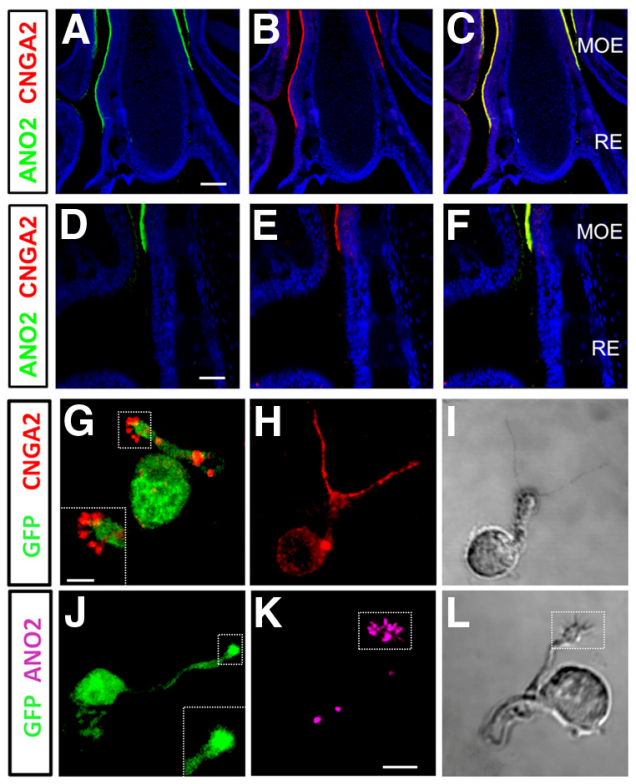

Figure 3. OSNs expressing GFP under control of the TRPM5 promoter (TRPM5-GFP ${ }^{+}$) express CNGA2 but not AN02. $\boldsymbol{A}-\boldsymbol{F}$, Immunohistochemistry for CNGA2 an AN02 in the ventral portion of the olfactory epithelium showing dorsally the MOE and ventrally the respiratory epithelium (RE). Double-label immunohistochemistry with the antibodies for CNGA2 (red) and AN02 (green) label the cilia layer of the olfactory epithelium, but not the cilia layer of the respiratory epithelium (more ventral). $\boldsymbol{A}, \boldsymbol{B}$, and $\boldsymbol{C}$ are presented at a lower magnification than $\boldsymbol{D}, \boldsymbol{E}$, and $\boldsymbol{F}$. $\boldsymbol{A}$ and $\boldsymbol{D}$ show immunolabeling for AN02 in green and nuclei in blue (stained with DAPI). $\boldsymbol{B}$ and $\boldsymbol{E}$ show immunolabeling for CNGA2 in red and nuclei in blue. $\boldsymbol{C}$ and $\boldsymbol{F}$ show immunolabeling for AN02 in green, for CNGA2 in red, and for nuclei in blue. Scales bars: $\boldsymbol{A}, 100 \mu \mathrm{m} ; \boldsymbol{D}$, $10 \mu \mathrm{m} . \mathbf{G}-\mathbf{L}$, Single-label immunohistochemistry obtained with the antibody for CNGA2 (red) or AN02 (purple) in OSNs isolated from TRPM5-GFP mice; green shows expression of GFP. G, Cilia in TRPM5-GFP ${ }^{+}$OSNs (GFP, green) immunoreacted to a CNGA2 antibody (red). Inset, Highermagnification image of the dendritic knob and cilia). $\boldsymbol{H}$, OSNs lacking GFP (TRPM5-GFPnegative; green) also immunoreacted to the CNGA2 antibody. $\boldsymbol{I}$, DIC micrograph of the cell in $\boldsymbol{H}$. $J$, TRPM5-GFP ${ }^{+}$OSNs were not immunolabeled by an ANO2 antibody (inset, purple; higher magnification image of the dendritic knob and cilia). $\boldsymbol{K}$, Cilia in TRPM5-GFP - OSNs were immunolabeled by the AN02 antibody. $\boldsymbol{L}, \mathrm{DIC}$ micrograph of the OSN in $\boldsymbol{K}$. Data in $\boldsymbol{G}-\boldsymbol{R}$ are representative of 10 TRPM5-GFP ${ }^{+}$and 10 TRPM5-GFP ${ }^{-}$OSNs. Scale bars: G-L, $1 \mu \mathrm{m}$.

pression of TRPM5 and CNGA2 in these cells. We re-examined this finding in individual cilia by performing immunocytochemistry in dissociated OSNs (Fig. 3). All the green fluorescent cells (TRPM5-GFP $^{+}$) expressed CNGA2 (Fig. $3 G$, red; $n=10$, and see Fig. $3 A-F)$, but did not immunoreact against the ANO2 antibody (Fig. 3J, purple; $n=10$ ). In contrast, in the GFP-negative OSNs (TRPM5-GFP ${ }^{-}$) we detected the expression of both CNGA2 and ANO2 in every single OSN [Fig. $3 H, K ; n=10$ (panels $I$ and $L$ show differential interference contrast (DIC) optics for the cells in panels $H$ and $K$ )].

These observations are consistent with the notion that all OSNs express CNGA2, but that there are two distinct subpopulations. One subpopulation expresses TRPM5 and lacks ANO2; the other subpopulation expresses ANO2 and is devoid (or expresses low levels; see Materials and Methods) of TRPM5. These findings suggest a fundamental difference in transduction between these subpopulations, leading us to ask whether pharmacological block of TRPM5 interfered with responses to pheromones.

Pharmacology indicates that TRPM5 mediates responses of TRPM5 GFP ${ }^{+}$OSNs to pheromones

If TRPM5 is involved in pheromone transduction (Lin et al., 2007), inhibition of this channel should suppress the pheromone 
loose-patch responses in the TRPM5expressing OSNs, but not in those lacking this channel. We tested the specific TRPM5 inhibitor TPPO (150 $\mu$; Palmer et al., 2010; Liu et al., 2011) on TRPM5$\mathrm{GFP}^{+} \mathrm{OSN}$, and found that this drug significantly decreased the pheromone response and that the effect was reversible (Figs. 4A-C). On average, TPPO reduced the response by $\sim 80 \%$ (Fig. $4 C$; $n=11$ ). In sharp contrast, TPPO had no effect on chemosensory loose-patch responses in OSNs that did not express GFP (TRPM5$\mathrm{GFP}^{-}$; Fig. $4 D-F ; n=12$ ). This differential effect of TPPO supports the requirement of TRPM5 for the response to pheromones in the specialized MOE OSNs, and indicates that the responses to pheromones in the TRPM5-GFP ${ }^{-}$ cells do not involve TRPM5.

In contrast, we found that the $\mathrm{Ca}^{2+}$ activated $\mathrm{Cl}^{-}$channel inhibitor niflumic acid blocks the odor and pheromone loose-patch responses of TRPM5-GFP ${ }^{-}$ OSNs (Fig. 4J-L), but did not affect the pheromone response of TRPM5-GFP ${ }^{+}$ OSNs (Fig. 4G-I). This result is consistent with the fact that TRPM5-GFP ${ }^{-}$OSNs express ANO2, but TRPM5-GFP ${ }^{+}$OSNs do not (Fig. 3).

\section{Activation of TRPM5 in TRPM5-GFP ${ }^{+}$ OSNs is coupled to the CNG channel through $\mathrm{Ca}^{2+}$ influx}

TRPM5 is a $\mathrm{Ca}^{2+}$-gated channel (Hofmann et al., 2003; Liu and Liman, 2003) that coexpresses with CNGA2 in the cilia (Fig. 3; Lin et al., 2007), presumably the only $\mathrm{Ca}^{2+}$ pathway from the external medium of the olfactory cilium (Schild and Restrepo, 1998). Therefore, inhibition of the CNG channel should decrease the pheromone response in TRPM5-expressing cells. Accordingly, the CNG channel inhibitor L-cis-diltiazem $(20 \mu \mathrm{M})$ greatly reduced the loose-patch current response to pheromones, as illustrated in the representative cell of Figure $5 A$; the cell fully recovered after removing the drug. On average, L-cis-diltiazem abolished $\sim 80 \%$ of the pheromone response (Fig. $5 B ; n=5$ ), suggesting that the CNG channel mediates the $\mathrm{Ca}^{2+}$ influx necessary for TRPM5 activation.

Since this result implies a $\mathrm{Ca}^{2+}$ increment in the cilium mediated by CNG, we surveyed inhibition by L-cis-diltiazem of intraciliary $\mathrm{Ca}^{2+}$ changes induced by pheromones in TRPM5$\mathrm{GFP}^{+} \mathrm{OSNs}$, measured with a confocal microscope in the linescan mode as an increase in fluorescence for the $\mathrm{Ca}^{2+}$ indicator X-rhod-1 (Fig. 5C-H). L-cis-diltiazem inhibited substantially pheromone-induced changes in $\mathrm{Ca}^{2+}$ (Fig. 5E, compare left and center), and the effect of the drug was reversible (Fig. $5 E$, right). Similar observations were obtained in five OSNs tested (Fig. $5 H$ ). Altogether, the results in Figure $5 A-H$ are consistent with CNG being crucial for TRPM5-expressing OSN responses to
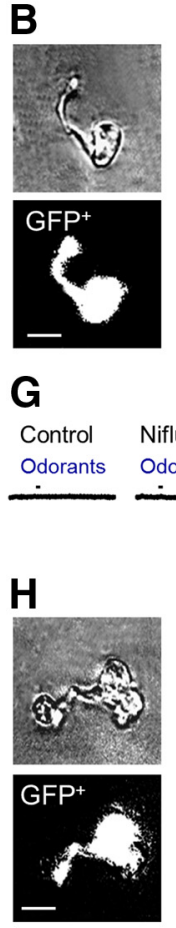
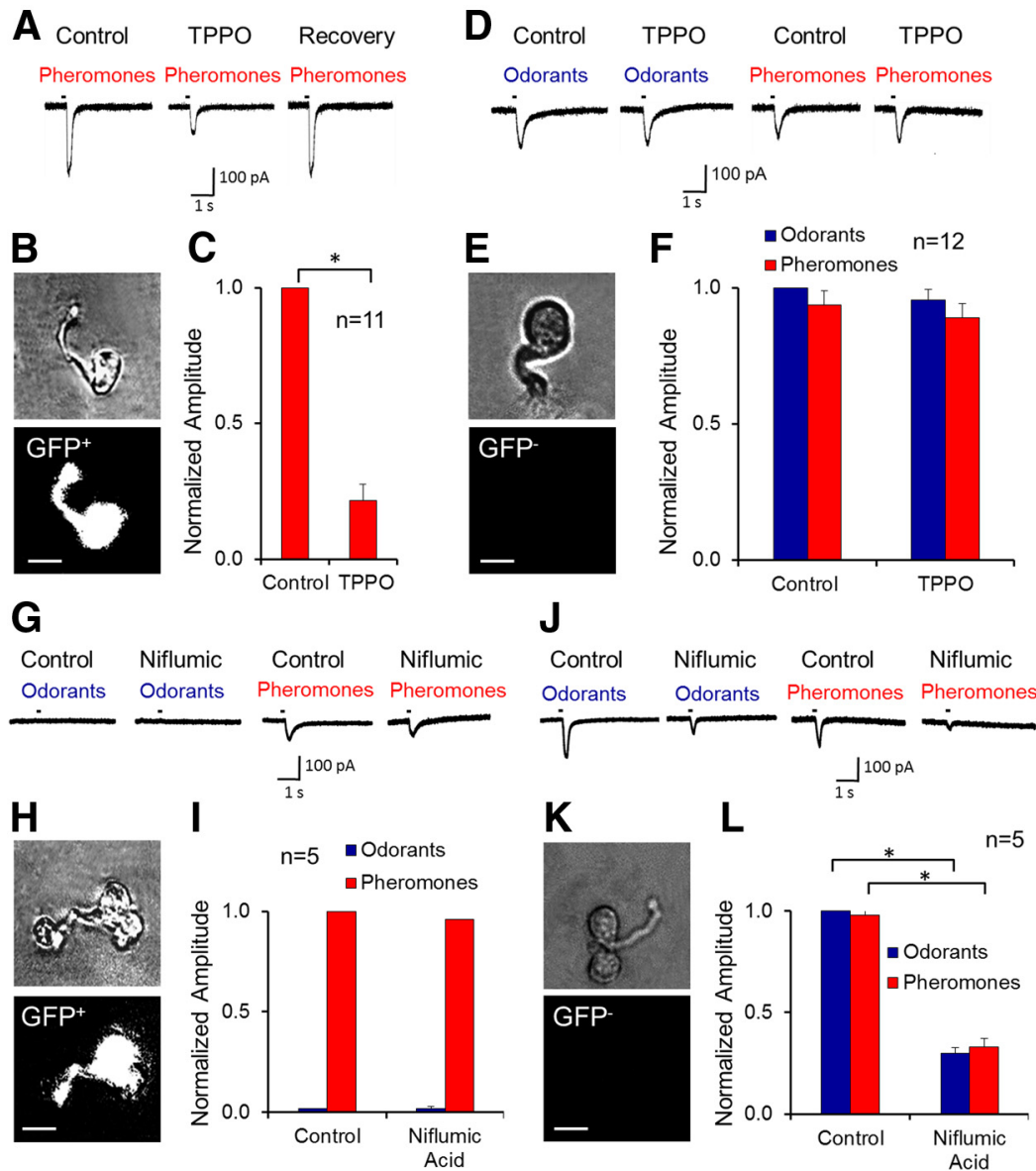

Figure 4. Blockage of TRPM5 with TPPO inhibits the pheromone responses in TRPM5-GFP ${ }^{+}$, but not in TRPM5-GFP ${ }^{-}$OSNs. $A$, $B$, Phase contrast (top) and fluorescence (GFP, bottom) view of the cell in $A$. C, Peaks of pheromone responses normalized to control (Wilcoxon rank sum test, $p<0.0001 ; n=11$ ). $\boldsymbol{D}$, Responses to odorants and pheromones of a TRPM5-GFP ${ }^{-}$OSN in the odorants normalized to responses to pheromones in the absence of TPPO (Wilcoxon rank sum test, $p>0.05, \mathrm{pFDR}=0.025 ; n=$ 12). $\mathbf{G}-\mathbf{I}$, Lack of an effect of niflumic acid $(300 \mu \mathrm{M})$, a blocker of $\mathrm{Ca}^{2+}$-activated $\mathrm{Cl}^{-}$channels, on loose-patch responses of OSNs stimulated with odorants and pheromones; control, niflumic acid-free Ringer's solution. G, Example of the lack 作 I, Average currents recorded in TRPM5-GFP ${ }^{+}$OSNs upon odorant and pheromone stimulation normalized to peaks of niflumic acid $(300 \mu \mathrm{m})$ on TRPM5-GFP ${ }^{-}$OSNs stimulated with odorants and pheromones. $J$. Example of a response of TRPM5GFP $^{-}$OSNs to odorants and pheromones in the absence/presence of niflumic acid. $\boldsymbol{K}$, Phase contrast and fluorescence view of the cell in J.L, Peak of the responses of TRPMS-GFP - OSNs to pheromones and odorants normalized to responses to pheromones in the absence of niflumic acid (Wilcoxon rank sum test, ${ }^{*} p<0.0001 ; n=5$ ). Error bars indicate SEM.

pheromones. In contrast, both pheromones and odorants elicited increases in $\mathrm{Ca}^{2+}$ in the cilia of TRPM5-GFP ${ }^{-}$OSNs (Fig. 5I-L).

As in previous studies in amphibian OSNs (Leinders-Zufall et al., 1998; Castillo et al., 2010), the stimulus-induced increases in $\mathrm{Ca}^{2+}$ in the cilia elicited in either the TRPM5-GFP ${ }^{+}$or the TRPM5-GFP ${ }^{-}$OSNs took place in microdomains $(0.2-0.5 \mu \mathrm{m}$; Fig. $5 C-G, I-K)$. Consistent with the studies in amphibian OSNs (Castillo et al., 2010), a single microdomain was found randomly located along the proximal $1 \mu \mathrm{m}$ along the cilium (Fig. $5 C, D$ ).

Pheromones increase intraciliary $\mathrm{Ca}^{2+}$ through $\mathrm{Ca}^{2+}$ influx in TRPM5-expressing OSNs

If the increase in intraciliary $\mathrm{Ca}^{2+}$ is mediated by extracellular $\mathrm{Ca}^{2+}$ influx through the CNG channel, as opposed to the release of $\mathrm{Ca}^{2+}$ from internal stores, then removing extracellular $\mathrm{Ca}^{2+}$ should inhibit the response. We examined this in TRPM5-GFP ${ }^{+}$ 

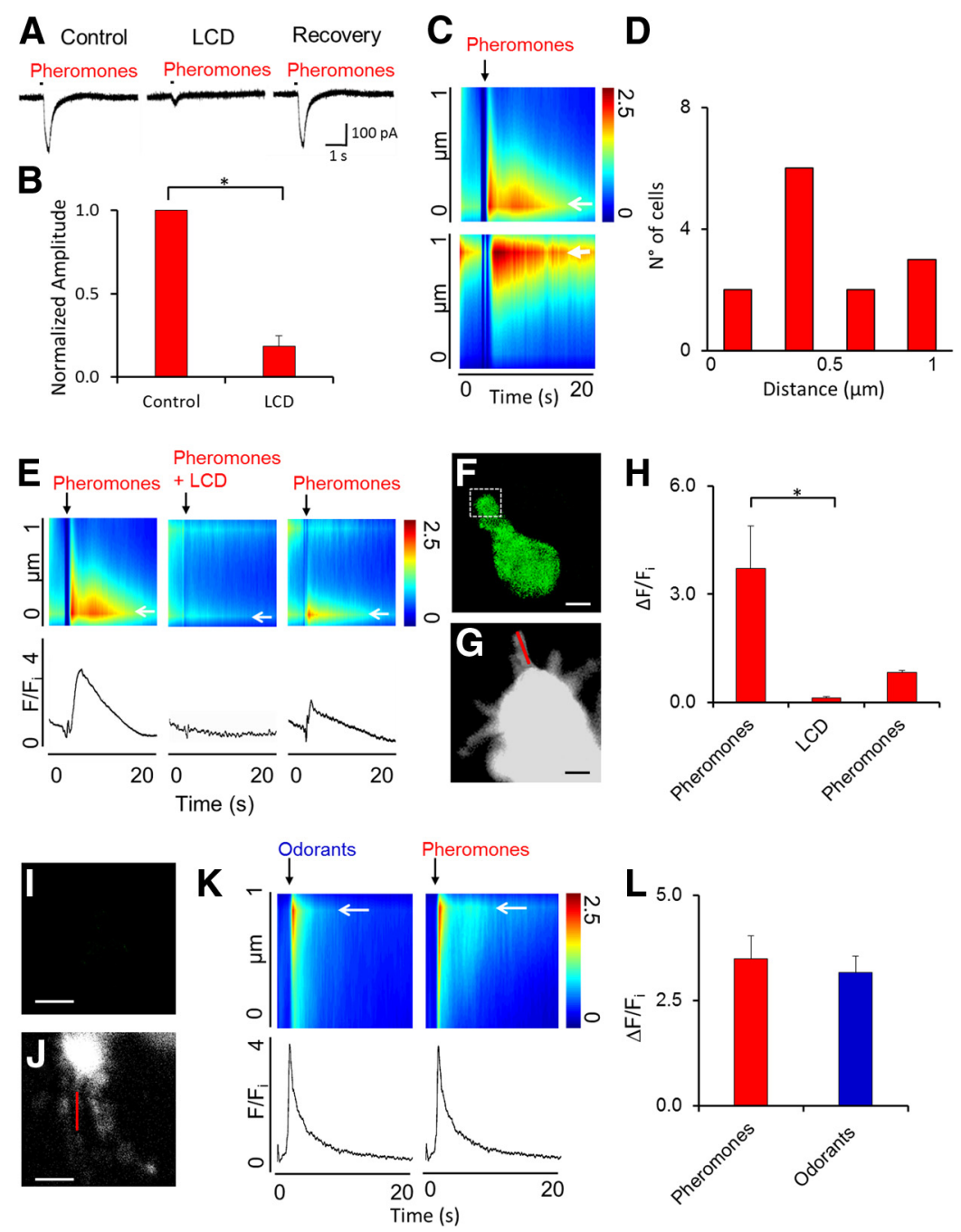

Figure 5. $\boldsymbol{A}-\boldsymbol{L}$, Stimulus-induced increase in intraciliary $\mathrm{Ca}^{2+}$ in TRPM5-GFP ${ }^{+}(\boldsymbol{A}-\boldsymbol{H})$ and TRPM5-GFP ${ }^{-}(\boldsymbol{I}-\boldsymbol{L})$ OSNs. $\boldsymbol{A}-\boldsymbol{H}$, Blockage of CNG abolishes the pheromone-induced loose-patch current and the pheromone-induced increase in intraciliary $\mathrm{Ca}^{2+}$ in TRPM5-GFP ${ }^{+}$OSNs. $A$, Example of a current response to pheromones in Ringer's solution, Ringer's solution supplemented with $20 \mu \mathrm{m}$ CNG inhibitor L-cis-diltiazem (LCD), and after washout. $B$, Bar plot comparing the average peak responses in the absence and presence of $\mathrm{L}$-cis-diltiazem for all cells studied (Wilcoxon rank sum test, $p<0.015$, pFDR $=0.05 ; n=4$ ). Error bars indicate SEM. $\boldsymbol{C}, \boldsymbol{D}$, Pheromones elicit discrete increases in intraciliary $\mathrm{Ca}^{2+}$. C, Two examples of pheromone-induced discrete increases in ciliary $\mathrm{Ca}^{2+}$ measured along the first $\mu \mathrm{m}$ along the cilium. Pseudocolor represents normalized $\mathrm{Ca}^{2+}$-dependent $\mathrm{X}$-rhod-1 fluorescence as a function of distance in the ciliary segment (ordinate) and time (abscissa; fluorescence has been normalized to the fluorescence during the $0.5 \mathrm{~s}$ before the addition of the pheromone). $\boldsymbol{D}$, Recording of the pheromone-elicited discrete increases in intraciliary $\mathrm{Ca}^{2+}$ in 13 different experiments show that the discrete increases in $\mathrm{Ca}^{2+}$ were located all along the length of the proximal cilium (measured in the first $1 \mu \mathrm{m}$ from the knob). $\boldsymbol{E}$, Example showing that L-cis-diltiazem inhibits the pheromone-induced discrete increase in intraciliary $\mathrm{Ca}^{2+}$. Top, Pseudocolor representation of normalized $\mathrm{Ca}^{2+}$-dependent $\mathrm{X}$-rhod-1 fluorescence as a function of distance in the ciliary segment (ordinate) and time (abscissa). Bottom, Time course of the relative fluorescence normalized to fluorescence before stimulation (F/Fi). $\mathrm{F}_{\mathrm{i}}$, Basal average fluorescence of the $0.5 \mathrm{~s}$ interval immediately preceding stimulation (arrow); black arrow, time of the pheromone stimulation, with and without L-cis-diltiazem. $\boldsymbol{F}$, GFP fluorescence for the OSN in $\boldsymbol{E}$. $\boldsymbol{G}, \mathrm{X}$-Rhod 1 fluorescence imaged in the olfactory knob and cilia in the OSN whose data are shown in $\boldsymbol{E}$. The red line is drawn in the cilium along which pheromoneinduced changes in $\mathrm{Ca}^{2+}$ were recorded. Fluorescence in the knob is saturated to obtain a detectable fluorescence signal from the cilium $(<0.2 \mu \mathrm{m}$ diameter). $\boldsymbol{H}$, Bar graph showing that L-cis-diltiazem inhibited the spatially discrete increases in intracellular $\mathrm{Ca}^{2+}$ elicited by pheromones in the TRPM5-GFP ${ }^{+}$OSN. Asterisks denote statistically significant differences compared with the first pheromone response control (Wilcoxon rank sum test, $p<0.02, \mathrm{pFDR}=0.05 ; n=5$ ). $I-L$, TRPM5-GFP ${ }^{-}$OSNs respond to pheromones and odorants. $I$, Lack of green fluorescence in a TRPM5-GFP ${ }^{-}$OSN. J, Cell loaded with X-rhod-1 at higher magnification. $\boldsymbol{K}$, Fluorescence changes along the first $1 \mu \mathrm{m}$ along the cilium in $\boldsymbol{B}$, upon stimulation with pheromones (left, top, and bottom) and with odorants (right, top, and bottom). Top, Pseudocolor representation of normalized $\mathrm{Ca}^{2+}$-dependent $\mathrm{X}$-rhod-1 fluorescence as a function of distance in the ciliary segment (ordinate) and time (abscissa). Bottom, Time course of the relative fluorescence normalized to fluorescence before stimulation (F/Fi). Black arrow, Time of the pheromone stimulation, with and without $L$-cis-diltiazem. $L$, Average peak responses to pheromones and odorants (Wilcoxon rank sum test, $p>0.05, \mathrm{pFDR}=0.05 ; n=5$ ). Error bars indicate SEM.
OSNs (Fig. 6A,B), which express CNGA2 (Fig. 3). A pheromonal stimulus elicited an increase in $\mathrm{Ca}^{2+}$-reporting fluorescence in the cilia bathed by normal extracellular solution (Fig. 6A). In contrast, odorants did not elicit an increase in $\mathrm{Ca}^{2+}$-reporting fluorescence measured in a cilium in these TRPM5-GFP ${ }^{+}$OSNs (Fig. 6A). This confirms the selectivity of TRPM5-GFP ${ }^{+}$OSNs for pheromones as measured in loose-patch recordings (Figs. $1,2)$. The $\mathrm{Ca}^{2+}$-induced fluorescence response to pheromones was absent when bathed in Ringer's solution with no $\mathrm{Ca}^{2+}$ $\left(0-\mathrm{Ca}^{2+}\right.$ solution $)$ and was recovered upon restoring external $\mathrm{Ca}^{2+}$ (Fig. 6A). Similar results were obtained in five cells tested (Fig. 6D). This result supports the participation of extracellular $\mathrm{Ca}^{2+}$ influx in the pheromone response and the involvement of CNG.

The fact that removal of extracellular $\mathrm{Ca}^{2+}$ causes a lack of an intraciliary $\mathrm{Ca}^{2+}$ increase elicited by pheromones (Fig. $6 A-D)$ raises the question of whether there are pheromone-induced current responses in the absence of extracellular $\mathrm{Ca}^{2+}$. In addition, inhibition of TRPM5 by TPPO leaves a relatively small pheromone-elicited current in TRPM5$\mathrm{GFP}^{+}$OSNs (Fig. 4C), which likely is mediated by the CNGA2 channel. Indeed, previous studies in OSNs have shown a relatively small CNG current left after inhibition of $\mathrm{Ca}^{2+}$-activated $\mathrm{Cl}^{-}$channels $(\sim 15 \%$ in mouse, Lowe and Gold, 1993; and $60 \%$ in the tiger salamander, Kurahashi and Yau, 1993). These observations raise the questions about whether the current left after blocking of TRPM5 in TRPM5-GFP ${ }^{+}$OSNs is the CNGdependent current, and whether this current is found in the absence of extracellular $\mathrm{Ca}^{2+} . \mathrm{Ca}^{2+}$ normally inhibits the CNG-dependent cationic current, and removal of extracellular $\mathrm{Ca}^{2+}$ relieves this inhibition, substantially increasing the current carried by $\mathrm{Na}^{+}$(Frings et al., 1995). Accordingly, Figure 6, E and $F$, shows that removal of extracellular $\mathrm{Ca}^{2+}$ elicited a large increase in pheromoneinduced loose-patch current in TRPM5$\mathrm{GFP}^{+}$OSNs. Consistent with the mediation of this current by CNG, the pheromoneinduced current was inhibited by the CNG blocker L-cis-diltiazem, but not by the TRPM5 blocker TPPO.

TRPM5 knockout abolishes pheromone responses of TRPM5-GFP ${ }^{+}$OSNs

Pharmacological experiments inhibiting responses to pheromones with TPPO suggest that TRPM5 mediates the phero- 

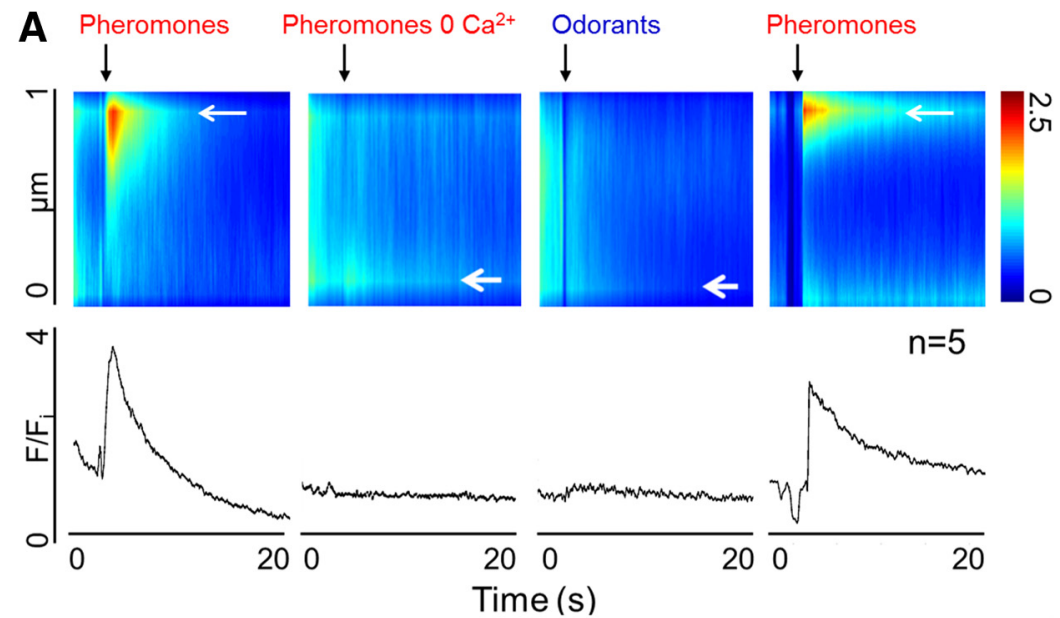

$n=5$

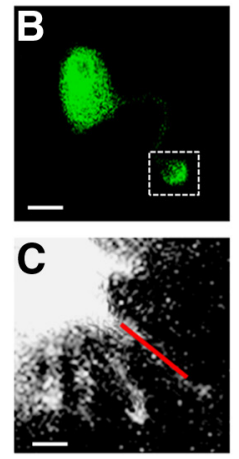

D

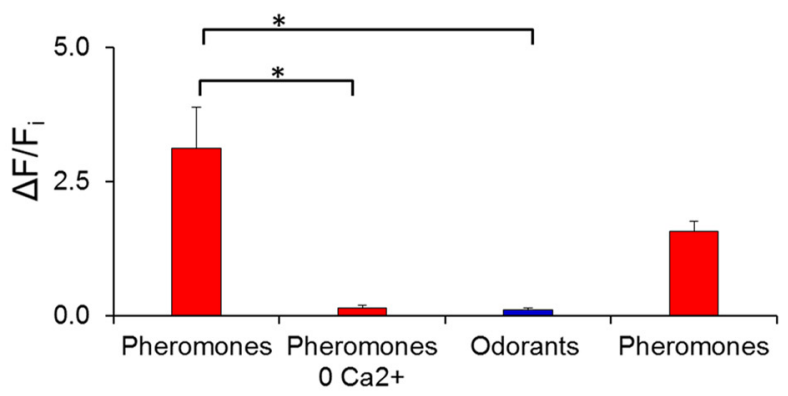

E
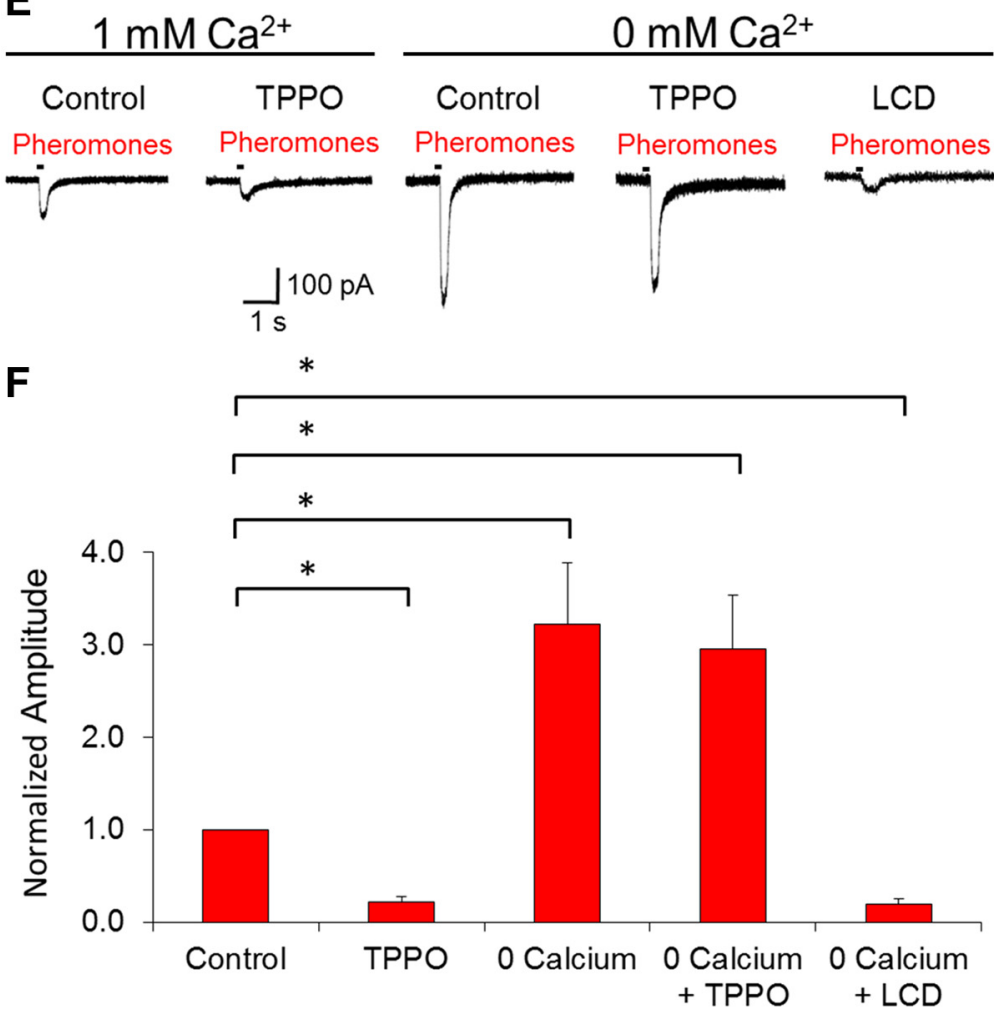

Figure 6. Dependence on extracellular $\mathrm{Ca}^{2+}$ of influx of $\mathrm{Ca}^{2+}$ into the cilia of the TRPM5-GFP ${ }^{+}$OSNs and related loose-patch response of TRPM5-GFP ${ }^{+}$OSNs to pheromones. $\boldsymbol{A}-\boldsymbol{D}$, Intraciliary $\mathrm{Ca}^{2+}$ responses of TRPM5-GFP ${ }^{+}$OSNs to pheromones require extracellular $\mathrm{Ca}^{2+} . \boldsymbol{A}$, Top, Discrete change in fluorescence (pseudocolor) elicited by pheromones along the proximal $1 \mu \mathrm{m}$ ciliary segment of the cilium (ordinate) induced by the chemical stimulus as a function of time (abscissa). The color code bar is shown to the right. Bottom, F/F $F_{i}$ as a function of time. $B$, GFP fluorescence from the TRPM5-GFP ${ }^{+}$OSN used to generate the data shown in A. C, Higher-magnification X-Rhod-1 fluorescence image of the dendritic knob and cilia. The red line denotes the segment of the cilium where the line-scan fluorescence recording in $\boldsymbol{C}$ was obtained. $\boldsymbol{D}$, Bar plot of the peak $\Delta \mathrm{F} / \mathrm{F}_{\mathrm{i}}$ results from five cells. Asterisks mone response in the specialized TRPM5$\mathrm{GFP}^{+}$olfactory neurons (Fig. 4). To explore the involvement of TRPM5 in pheromone responses using an independent approach, we generated TRPM5KO-GFP mice by the cross of TRPM5-KO mice with transgenic TRPM5-GFP mice expressing GFP under the control of the TRPM5 promoter. Consistent with experiments in TRPM5-GFP mice (Fig. 3), the green neurons isolated from the TRPM5KO-GFP mice exhibited CNGA2 but not ANO2 labeling in their cilia (Fig. $7 A, D$; $n=10$ ). In addition, GFP-negative OSNs were identified with light microscopy under fluorescence and DIC optics (Fig. $7 C, F)$, which were also consistent with TRPM5-GFP mice, the cilia of the nonfluorescent OSN subpopulation isolated from TRPM5-KO-GFP mice immunoreacted with both CNGA2 and ANO2 (Fig. $7 B, E ; n=10)$.

If TRPM5 mediates pheromonal responses, then the green fluorescent olfactory neurons of TRPM5-KO-GFP mice should not be able to respond to pheromones. Similarly, since TRPM5-GFP ${ }^{-}$ OSNs express ANO2 (Fig. 3), we predict that they would respond to pheromones and odorants in these knock-out mice. Figure 7 confirms that TRPM5-GFP ${ }^{-}$ OSNs isolated from TRPM5-KO-GFP mice responded to both odorants and pheromones, and that, consistent with pharmacological experiments (Fig. 4), the responses of TRPM5-GFP ${ }^{-}$OSNs to odors and pheromones do not depend on the expression of TRPM5. Indeed, consistent with the experiments in OSNs isolated from TRPM5-GFP mice (Fig. 1), $43 \%$ of the 35 TRPM5-GFP ${ }^{-}$OSNs tested with loose-patch modality from TRPM5KO-GFP mice responded to odors and/or pheromones by a change in current larger than $2 \times$ the SEM of the current before stimulation. In contrast, TRPM5-GFP ${ }^{+}$ OSNs isolated from TRPM5-KO-GFP mice responded to pheromones (or odors) with a significantly smaller peak current (Fig. 7J). This is in contrast to

\section{$\leftarrow$}

denote significant differences in $\Delta \mathrm{F} / \mathrm{F}_{\mathrm{i}}$ (Wilcoxon rank sum test, $p<0.0001, \mathrm{pFDR}=0.03 ; n=5$ ). Error bars indicate SEM. $E, F$, Dependence on extracellular $\mathrm{Ca}^{2+}$ of loose-patch responses to pheromones of TRPM5-GFP ${ }^{+}$OSNs. E, Responses to pheromones by a TRPM5-GFP ${ }^{+}$OSN in Ringer's solution with 1 and $0 \mathrm{~mm} \mathrm{Ca}^{2+}$ Ringer's solution. Under $1 \mathrm{~mm} \mathrm{Ca}^{2+}$, it was treated with TPPO, and under $0-\mathrm{Ca}^{2+}$ it was treated with TPPO and then with L-cis-diltiazem. $\boldsymbol{F}$, Peaks of the responses to pheromones of TRPMS-GFP ${ }^{+}$OSN as in E. Asterisks indicate Wilcoxon rank sum test differences $(p<0.015, \mathrm{pFDR}=0.05$; $n=12)$. 


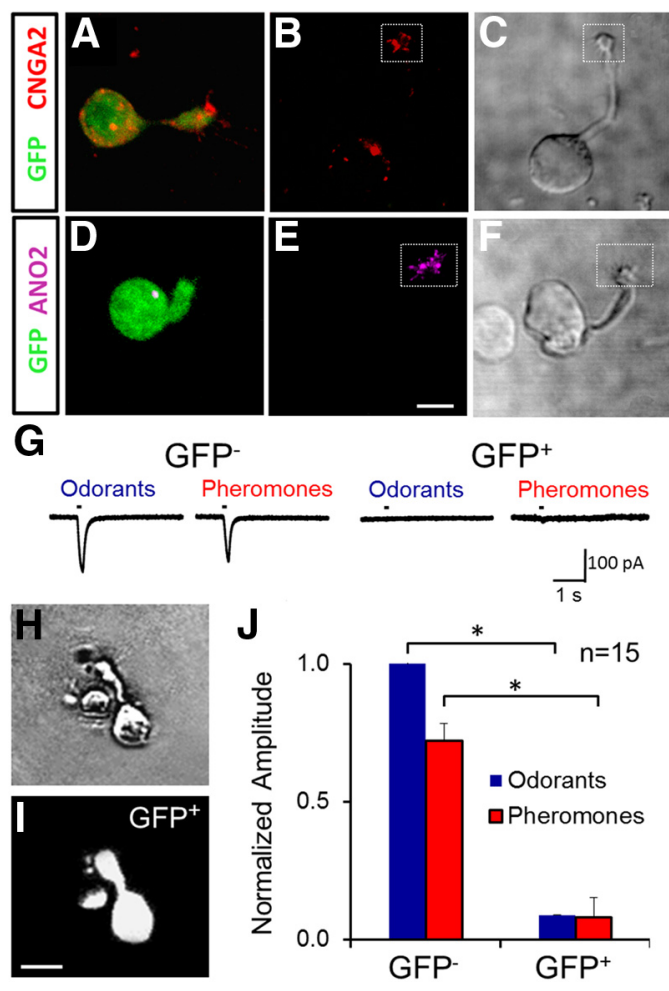

Figure 7. TRPM5 knockout substantially diminishes loose-patch responses of chemosensory neurons expressing GFP in TRPM5 GFP mice. $\boldsymbol{A}-\boldsymbol{F}$, Single-label immunohistochemistry obtained with the antibodies for CNGA2 (red) and ANO2 (purple) in OSNs isolated from TRPM5-GFP/ knock-out mice. TRPM5-K0-GFP ${ }^{+}$OSNs express CNGA2 but not AN02. A, D, Images of TRPM5(GFP)-expressing OSNs (green) isolated from TRPM5-KO-GFP mouse immunoreacted with an antibody against CNGA2 ( $\boldsymbol{A}$, red) or AN02 (D, purple). $\boldsymbol{B}, \boldsymbol{E}$, Images of OSNs that do not express TRPM5 (negative, green) immunoreacted with an antibody against CNGA2 ( $\boldsymbol{B}$, red) or AN02 ( $\boldsymbol{E}$, purple). GFP-negative OSNs in $\boldsymbol{B}$ and $\boldsymbol{E}$ were searched for using light microscopy under DIC optics $(\boldsymbol{C}, \boldsymbol{F})$. Data shown for each experiment are representative of images of 10 OSNs. Data are representative of 10 TRPM5-GFP ${ }^{+}$and 10 TRPM5-GFP ${ }^{-}$OSNs. Scale bars, $1 \mu \mathrm{m}$. G-J, Loosepatch responses of OSNs from TRPM5-KO mice to pheromones and odorants. G, Examples of loose-patch responses to pheromones in a GFP ${ }^{-}$OSN and a GFP ${ }^{+}$OSN. $\boldsymbol{H}, \mathbf{I}$, Photograph of a TRPM5-K0-GFP ${ }^{+}$OSN under phase contrast $(\boldsymbol{H})$ and GFP fluorescence optics $(\boldsymbol{I})$. J, Peaks of pheromone and odorant loose-patch responses in TRPM5-KO-GFP ${ }^{-}$and TRPM5-KO-GFP ${ }^{+}$ OSNs (Wilcoxon rank sum test, $p<0.0001 ; n=15$ for both TRPM5-KO-GFP ${ }^{+}$and TRPM5-KO$\mathrm{GFP}^{-}$OSNs). Error bars indicate SEM.

TRPM5-GFP $^{+}$OSNs isolated from TRPM5-GFP mice (Fig. 1). These results show that TRPM5 is necessary for the pheromonal responses of TRPM5-GFP ${ }^{+}$OSNs.

TRPM5 currents recorded in inside-out patches from the cilia of TRPM5-expressing OSNs

Immunohistochemical studies have shown that TRPM5 is expressed in the ciliary layer of the olfactory epithelium, suggesting expression of this channel in the olfactory cilia (Lin et al., 2007; Oshimoto et al., 2013). To determine whether TRPM5-GFP ${ }^{+}$ OSNs express a functional TRPM5 nonspecific cation channel in the cilia, we recorded $\mathrm{Ca}^{2+}$-induced currents in inside-out patches excised from OSN cilia (Fig. 8). To verify that it was a cation conducting channel and not a $\mathrm{Cl}^{-}$channel, we used solutions with a $\mathrm{Na}^{+}$gradient and free of $\mathrm{K}^{+}$. We recorded currents consistent with a cation-conducting channel with a pronounced $\mathrm{Ca}^{2+}$ dependence, as shown by the dramatic increase in channel activity between 1.2 and $50 \mu \mathrm{M} \mathrm{Ca}^{2+}$ in the cytoplasmic side (Fig. $8 A ; n=3$ of 3 ; Hofmann et al., 2003; Liu and Liman, 2003). To confirm the identity of this channel, we tested the inhibition of the TRPM 5 channel by TPPO $(150 \mu \mathrm{M})$ under $8 \mu \mathrm{M}$ cytoplasmic $\mathrm{Ca}^{2+}$; as in the loose-patch experiments, the drug strongly and reversibly inhibited the channel (Fig. $8 C ; n=3$ ). In addition, we explored the possibility that the TRPM 5 channel could be also found in the conventional OSNs, by recording excised cilia patches from TRPM5-GFP ${ }^{-}$OSNs. In all TRPM5-GFP ${ }^{-}$OSN experiments, the patches were silent, but cAMP application induced activity, indicating that CNG channels were present (Fig. $8 D ; n=4)$. Accordingly, subsequent addition of TPPO did not have an effect. These results support the presence of TRPM5 channels in the cilia of the TRPM5-GFP ${ }^{+}$neurons.

\section{Discussion}

Here we demonstrate the presence of a subpopulation of OSNs in the MOE that selectively responds to pheromones, urine, and MHC peptides, but not odorants. This subset of OSNs expresses TRPM5 in the cilia and has a novel transduction pathway. These $\mathrm{TRPM}^{+}$OSNs respond to pheromones and related stimuli through activation of $\mathrm{CNG}$, leading to ciliary influx of $\mathrm{Ca}^{2+}$ that elicits depolarization by opening of the $\mathrm{Ca}^{2+}$-activated TRPM5 nonselective cation channel (Fig. 9). In contrast, in the other TRPM5 ${ }^{-}$OSNs of this neuroepithelium that express CNG and ANO2, but not TRPM5, which constitutes the majority of the sensory receptor cells, the influx of $\mathrm{Ca}^{2+}$ elicited by odorants through the CNG channel results in depolarization, presumably through the opening of the $\mathrm{Ca}^{2+}$-activated $\mathrm{Cl}^{-}$channels. Finally, we find that ANO2-expressing OSNs can also respond to pheromones at high concentration. It is not at all clear why these OSNs respond to pheromones, and future work should determine whether at higher concentrations pheromones are detected as odorants by these neurons. Interestingly, humans can smell the pheromone-related molecules used in this study, and they likely would respond at high concentrations of androstadienone (Hummer and McClintock, 2009).

The data supporting the model for involvement of TRPM5 in transduction in TRPM5 ${ }^{+}$OSNs (Fig. 9) are as follows: (1) immunohistochemistry in Figure 3 indicates that CNGA2 is expressed in both TRPM5-GFP-positive and -negative OSNs, but ANO2 is present only in GFP-negative OSNs; (2) previous immunohistochemical studies (Lin et al., 2007; Oshimoto et al., 2013) and the patch-clamp experiments of olfactory cilia in Figure 8 support the idea that in TRPM5-GFP ${ }^{+}$OSNs the cilia express TRPM5; (3) there is inhibition of pheromone responses in $\mathrm{TRPM}-\mathrm{GFP}^{+}$OSNs, but not in TRPM5-GFP ${ }^{-}$OSNs, by the TRPM5 inhibitor TPPO (Fig. 4); (4) in sharp contrast, there is inhibition of pheromone (and odor) responses in TRPM5-GFP OSNs, but not in TRPM5-GFP ${ }^{+}$OSNs, by the $\mathrm{Ca}^{2+}$-activated $\mathrm{Cl}^{-}$channel inhibitor niflumic acid (Fig. 4); (5) knockout of TRPM5 decreases pheromonal responses in TRPM5-GFP ${ }^{+}$ OSNs, but not in TRPM5-GFP ${ }^{-}$OSNs (Fig. 7); (6) inhibition of the $\mathrm{Ca}^{2+}$ influx and loose-patch current in TRPM5-GFP ${ }^{+}$(and $\mathrm{GFP}^{-}$) OSNs by the CNG channel inhibitor L-cis-diltiazem (Fig. 5 ) is consistent with the mediation of the response by CNG; (7) the pheromone-induced ciliary $\mathrm{Ca}^{2+}$ increase in TRPM5-GFP ${ }^{+}$ OSNs is dependent on external $\mathrm{Ca}^{2+}$, indicating that it is due to extracellular influx (Fig. 6); and (8) TRPM5-dependent currents are exclusively observed in excised cilia patches from TRPM5$\mathrm{GFP}^{+}$but not from TRPM5-GFP ${ }^{-}$OSNs (Fig. 8). Together, these data support pheromone and odor transduction by different pathways in OSNs (Fig. 9). Importantly, the exclusive use of pharmacological inhibitors can be problematic; however, in this study it was key that the inhibitors yielded differential effects 
in $\mathrm{TRPM}^{-\mathrm{GFP}^{+}}$and TRPM5-GFP ${ }^{-}$ OSNs, and that the effect of TRPM5 knockout was complementary.

The VNO was traditionally considered to be the murine "pheromone detection system" that sends information to the vomeronasal medial amygdala, while the olfactory epithelium was considered to be the system for detection of nonpheromonal (general) odorants sending information to the piriform (olfactory) cortex (Dulac and Torello, 2003; Halpern and Martínez-Marcos, 2003). Nevertheless, in past experiments it was shown that the main olfactory system responded to pheromones (Teicher et al., 1980; Dorries et al., 1995), and recently it has become clear that a subset of mitral cells in the main olfactory bulb sends axons to the vomeronasal amygdala (Pro-Sistiaga et al., 2007; Kang et al., 2009; Thompson et al., 2012), raising the question of whether a subset of main olfactory system OSNs detect pheromones to convey information to the vomeronasal amygdala. In parallel studies, the knockout of proteins involved in the cAMP main olfactory transduction pathway elicited the failure of maternal behavior (knockouts of $\mathrm{G}_{\text {olf }}$; Belluscio et al., 1998). In addition, knockout of ACIII (Wang and Storm, 2011) and CNGA2 (Lin et al., 2004; Spehr et al., 2006b) strongly abolish the MOE EOG responses to pheromones. These data suggest that cAMP transduction in OSNs in the main olfactory system is likely involved in a subset of pheromonal responses.

The direct study of OSNs that express CNG and TRPM5 was necessary to examine the role of TRPM5 in pheromonal transduction (Zufall and Leinders-Zufall, 2007; Munger et al., 2009). In particular, the involvement of TRPM5 in the transduction cascade for high-sensitivity responses of pheromones (and related stimuli) by TRPM5-GFP ${ }^{+}$OSNs (Fig. 1) and the fact that these cells target glomeruli innervated by mitral cells that send their axons to the medial amygdala (Thompson et al., 2012) indicate that a subset of OSNs expressing TRPM5 are involved in conveying pheromonal information (Fig. 9). In addition, TRPM5 is expressed in what is likely a subset of vomeronasal sensory neurons that may also be involved in conveying pheromonal information (Kaske et al., 2007). In addition, a small fraction $(<10 \%)$ of solitary chemoreceptor cells (Lin et al., 2008) expressing GFP in TRPM5-GFP mice respond to DMP, but only at relatively high concentrations ( 12.5 and $500 \mu \mathrm{M}$, respectively). Future studies should determine whether TRPM5-expressing OSNs are involved in pheromonal behavior mediated by the MOE in mouse (Belluscio et al., 1998; Mandiyan et al., 2005; Wang et al., 2006; Wang and Storm, 2011).

We find that TRPM5-expressing OSNs are ultrasensitive, responding to concentrations of pheromones and related compounds as low as $12.5 \mathrm{nM}$. It is informative to compare the responsiveness previously reported for MOE OSNs to MHC peptides (Spehr et al., 2006a) and for VSNs to pheromones and MHC peptides (Leinders-Zufall et al., 2000, 2004). Figure 1 shows that the TRPM5-expressing OSNs respond to DMP at $12.5 \mathrm{nM}$, a con-

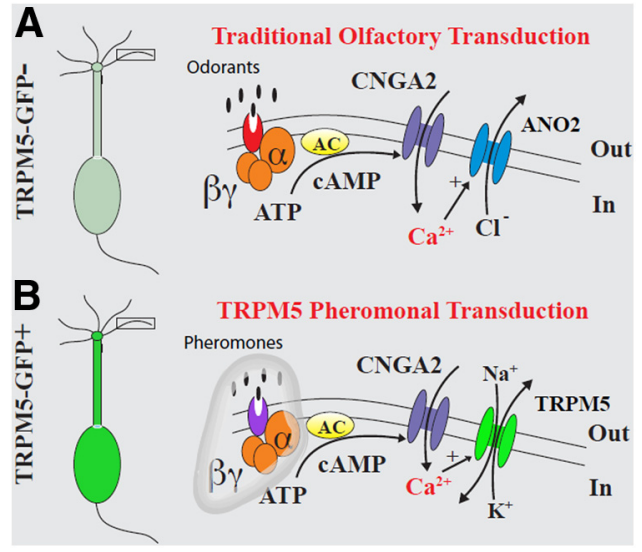

Figure 9. A, Diagrams showing the traditional ciliary olfactory pathway found in OSNs devoid of GFP fluorescence in TRPM5-GFP mice (TRPM5-GFP ${ }^{-}$cells). $\boldsymbol{B}$, In this work, we show that CNGA2 and TRPM5 5 are involved in pheromonal transduction in the TRPM5- GFP ${ }^{+}$OSNs. This diagram shows the pheromonal TRPM5 transduction pathway that we propose based on these experiments and the work of Wang and Storm, 2011 implicating the involvement of ACIII in pheromonal responses. As in odorant transduction, both pathways implicate the CNG and a role of $\mathrm{Ca}^{2+}$ entering through this channel activating ANO2 and TRPM5 in odorant and pheromone transduction, respectively. Whether $G_{\text {off }}$ is involved in pheromone transduction in these cells as well, and which proteins are the pheromone receptors, remain to be determined.

centration that does not elicit responses in VSNs (Leinders-Zufall et al., 2000). Furthermore, the response of TRPM5-expressing OSNs to DMP, 2-heptanone, and peptides takes place at nanomolar concentrations (Figs. 1, 2), but the responses of VSNs and other OSNs to these compounds take place at lower concentra- 
tions (Leinders-Zufall et al., 2000, 2004; Spehr et al., 2006b). Interestingly, MOE OSNs have been previously shown to respond to multiple peptides or to peptides and 2-heptanone (Spehr et al., 2006a). In contrast, VSNs respond to only one pheromonal stimulus even at high concentration (100 nM; LeindersZufall et al., 2000). Finally TRPM5-expressing OSNs did not respond even at high concentration $(12.5 \mu \mathrm{M})$ to $\mathrm{E}-\beta$-farnesene, a pheromone that elicits responses in the VSNs at concentrations down to $0.1 \mathrm{~nm}$ (Leinders-Zufall et al., 2000). Thus, the subset of TRPM5-expressing OSNs studied here responds to DMP and other pheromonal stimuli at a low nanomolar concentration. However, in future experiments it will be key to perform more characterizations of the responsiveness of TRPM5-expressing OSNs to different pheromones and odors.

Previous studies indicated that operant conditioning (go-no go) experiments did not show differences in odor discrimination between TRPM5 knock-out and control mice (Lin et al., 2007). One explanation is that, as we show, the TRPM5-GFP ${ }^{-}$OSNs respond to high concentrations of pheromones. These responses by cells that do not express TRPM5 may provide sufficient information to olfactory bulb/piriform cortex for the previous odor discrimination experiments, but are likely not providing sufficient information to medial amygdala (Thompson et al., 2012). Therefore, our data indicate that TRPM5-expressing OSNs are involved in pheromonal behavior, but likely are not involved in the detection of odors. Future studies are necessary to resolve this question.

In summary, the combined immunohistochemical, ciliary $\mathrm{Ca}^{2+}$ imaging, and loose- and excised patch recordings are consistent with a pheromonal second messenger pathway found in a subset of OSNs where pheromones elicit CNG-mediated increases in ciliary $\mathrm{Ca}^{2+}$ that cause opening of the $\mathrm{Ca}^{2+}$-activated nonspecific cation channel TRPM5, thereby leading to cell depolarization (Fig. 9). Together with immunohistochemical localization of TRPM5 to the cilia layer (Lin et al., 2007), these data show that a subset of OSNs in the MOE responds to pheromones using the TRPM5 transduction pathway. Because OSNs expressing TRPM5 target a subset of glomeruli innervated by mitral cells sending axons to the medial vomeronasal amygdala (Thompson et al., 2012), our findings support the notion that a fraction of cells in the main olfactory system contribute to pheromonal responses. This discovery is particularly relevant for future studies in humans and higher primates, where it is suspected that there are responses to pheromones, and yet the vomeronasal system appears to be nonfunctional (Trotier, 2011). Relevant to this study, putative human male axillary pheromone enhances females' rating of male sexual attractiveness as well as their sexual arousal (Wyart et al., 2007; Saxton et al., 2008). Indeed, our study raises the question whether pheromonal responses in higher primates are mediated by a subset of OSNs in the MOE.

\section{References}

Bakalyar HA, Reed RR (1990) Identification of a specialized adenylyl cyclase that may mediate odorant detection. Science 250:1403-1406. CrossRef Medline

Baker H, Cummings DM, Munger SD, Margolis JW, Franzen L, Reed RR, Margolis FL (1999) Targeted deletion of a cyclic nucleotide-gated channel subunit (OCNC1): biochemical and morphological consequences in adult mice. J Neurosci 19:9313-9321. Medline

Baum MJ (2012) Contribution of pheromones processed by the main olfactory system to mate recognition in female mammals. Front Neuroanat 6:20. CrossRef Medline

Belluscio L, Gold GH, Nemes A, Axel R (1998) Mice deficient in G(olf) are anosmic. Neuron 20:69-81. CrossRef Medline

Billig GM, Pál B, Fidzinski P, Jentsch TJ (2011) Ca(2+)-activated Cl(-) cur- rents are dispensable for olfaction. Nat Neurosci 14:763-769. CrossRef Medline

Castillo K, Restrepo D, Bacigalupo J (2010) Cellular and molecular Ca2+ microdomains in olfactory cilia support low signaling amplification of odor transduction. Eur J Neurosci 32:932-938. CrossRef Medline

Clapp TR, Medler KF, Damak S, Margolskee RF, Kinnamon SC (2006) Mouse taste cells with $\mathrm{G}$ protein-coupled taste receptors lack voltagegated calcium channels and SNAP-25. BMC Biol 4:7. CrossRef Medline

Curran-Everett D (2000) Multiple comparisons: philosophies and illustrations. Am J Physiol Regul Integr Comp Physiol 279:R1-R8. Medline

Damak S, Rong M, Yasumatsu K, Kokrashvili Z, Pérez CA, Shigemura N, Yoshida R, Mosinger B Jr, Glendinning JI, Ninomiya Y, Margolskee RF (2006) Trpm5 null mice respond to bitter, sweet, and umami compounds. Chem Senses 31:253-264. CrossRef Medline

Ding Y, Wilkins D (2004) The effect of normalization on microarray data analysis. DNA Cell Biol 23:635-642. CrossRef Medline

Dorries KM, Adkins-Regan E, Halpern BP (1995) Olfactory sensitivity to the pheromone, androstenone, is sexually dimorphic in the pig. Physiol Behav 57:255-259. CrossRef Medline

Dulac C, Torello AT (2003) Molecular detection of pheromone signals in mammals: from genes to behaviour. Nat Rev Neurosci 4:551-562. CrossRef Medline

Finger TE, Silver WL, Restrepo D (2000) The neurobiology of taste and smell, Ed 2. New York: Wiley.

Firestein S, Werblin F (1989) Odor-induced membrane currents in vertebrateolfactory receptor neurons. Science 244:79-82. CrossRef Medline

Frings S, Seifert R, Godde M, Kaupp UB (1995) Profoundly different calcium permeation and blockage determine the specific function of distinct cyclic nucleotide-gated channels. Neuron 15:169-179. CrossRef Medline

Gonzalez-Silva C, Vera J, Bono MR, González-Billault C, Baxter B, Hansen A, Lopez R, Gibson EA, Restrepo D, Bacigalupo J (2013) Ca2+-activated $\mathrm{Cl}$ - channels of the $\mathrm{ClCa}$ family express in the cilia of a subset of rat olfactory sensory neurons. PLoS One 8:e69295. CrossRef Medline

Halpern M, Martínez-Marcos A (2003) Structure and function of the vomeronasal system: an update. Prog Neurobiol 70:245-318. CrossRef Medline

Hofmann T, Chubanov V, Gudermann T, Montell C (2003) TRPM5 is a voltage-modulated and $\mathrm{Ca}(2+)$-activated monovalent selective cation channel. Curr Biol 13:1153-1158. CrossRef Medline

Hummer TA, McClintock MK (2009) Putative human pheromone androstadienone attunes the mind specifically to emotional information. Horm Behav 55:548-559. CrossRef Medline

Jones DT, Reed RR (1989) Golf: an olfactory neuron specific-G protein involved in odorant signal transduction. Science 244:790-795. CrossRef Medline

Kang N, Baum MJ, Cherry JA (2009) A direct main olfactory bulb projection to the 'vomeronasal' amygdala in female mice selectively responds to volatile pheromones from males. Eur J Neurosci 29:624-634. CrossRef Medline

Kaske S, Krasteva G, König P, Kummer W, Hofmann T, Gudermann T, Chubanov V (2007) TRPM5, a taste-signaling transient receptor potential ion-channel, is a ubiquitous signaling component in chemosensory cells. BMC Neurosci 8:49. CrossRef Medline

Kleene SJ, Gesteland RC (1991) Calcium-activated chloride conductance in frog olfactory cilia. J Neurosci 11:3624-3629. Medline

Kurahashi T, Yau KW (1993) Co-existence of cationic and chloride components in odorant-induced current of vertebrate olfactory receptor cells. Nature 363:71-74. CrossRef Medline

Leinders-Zufall T, Greer CA, Shepherd GM, Zufall F (1998) Imaging odorinduced calcium transients in single olfactory cilia: specificity of activation and role in transduction. J Neurosci 18:5630-5639. Medline

Leinders-Zufall T, Lane AP, Puche AC, Ma W, Novotny MV, Shipley MT, Zufall F (2000) Ultrasensitive pheromone detection by mammalian vomeronasal neurons. Nature 405:792-796. CrossRef Medline

Leinders-Zufall T, Brennan P, Widmayer P, S PC, Maul-Pavicic A, Jäger M, Li XH, Breer H, Zufall F, Boehm T (2004) MHC class I peptides as chemosensory signals in the vomeronasal organ. Science 306:1033-1037. CrossRef Medline

Lin W, Arellano J, Slotnick B, Restrepo D (2004) Odors detected by mice deficient in cyclic nucleotide-gated channel subunit A2 stimulate the main olfactory system. J Neurosci 24:3703-3710. CrossRef Medline

Lin W, Margolskee R, Donnert G, Hell SW, Restrepo D (2007) Olfactory neurons expressing transient receptor potential channel M5 (TRPM5) are 
involved in sensing semiochemicals. Proc Natl Acad Sci U S A 104:24712476. CrossRef Medline

Lin W, Ogura T, Margolskee RF, Finger TE, Restrepo D (2008) TRPM5expressing solitary chemosensory cells respond to odorous irritants. J Neurophysiol 99:1451-1460. CrossRef Medline

Liu D, Liman ER (2003) Intracellular Ca2 + and the phospholipid PIP2 regulate the taste transduction ion channel TRPM5. Proc Natl Acad Sci U S A 100:15160-15165. CrossRef Medline

Liu P, Shah BP, Croasdell S, Gilbertson TA (2011) Transient receptor potential channel type M5 is essential for fat taste. J Neurosci 31:8634-8642. CrossRef Medline

Lowe G, Gold GH (1993) Nonlinear amplification by calcium-dependent chloride channels in olfactory receptor cells. Nature 366:283-286. CrossRef Medline

Ma M (2012) Odor and pheromone sensing via chemoreceptors. Adv Exp Med Biol 739:93-106. CrossRef Medline

Mandiyan VS, Coats JK, Shah NM (2005) Deficits in sexual and aggressive behaviors in Cnga2 mutant mice. Nat Neurosci 8:1660-1662. CrossRef Medline

Menco BP (1997) Ultrastructural aspects of olfactory signaling. Chem Senses 22:295-311. CrossRef Medline

Munger SD, Leinders-Zufall T, Zufall F (2009) Subsystem organization of the mammalian sense of smell. Annu Rev Physiol 71:115-140. CrossRef Medline

Nakamura T, Gold GH (1987) A cyclic nucleotide-gated conductance in olfactory receptor cilia. Nature 325:442-444. CrossRef Medline

Novotny M, Harvey S, Jemiolo B (1990) Chemistry of male dominance in the house mouse, Mus domesticus. Experientia 46:109-113. CrossRef Medline

Oshimoto A, Wakabayashi Y, Garske A, Lopez R, Rolen S, Flowers M, Arevalo N, Restrepo D (2013) Potential role of transient receptor potential channel M5 in sensing putative pheromones in mouse olfactory sensory neurons. PLoS One 8:e61990. CrossRef Medline

Palmer RK, Atwal K, Bakaj I, Carlucci-Derbyshire S, Buber MT, Cerne R, Cortés RY, Devantier HR, Jorgensen V, Pawlyk A, Lee SP, Sprous DG, Zhang Z, Bryant R (2010) Triphenylphosphine oxide is a potent and selective inhibitor of the transient receptor potential melastatin-5 ion channel. Assay Drug Dev Technol 8:703-713. CrossRef Medline

Pro-Sistiaga P, Mohedano-Moriano A, Ubeda-Bañon I, Del Mar ArroyoJimenez M, Marcos P, Artacho-Pérula E, Crespo C, Insausti R, MartinezMarcos A (2007) Convergence of olfactory and vomeronasal projections in the rat basal telencephalon. J Comp Neurol 504:346-362. CrossRef Medline

Rasche S, Toetter B, Adler J, Tschapek A, Doerner JF, Kurtenbach S, Hatt H, Meyer H, Warscheid B, Neuhaus EM (2010) Tmem16b is specifically expressed in the cilia of olfactory sensory neurons. Chem Senses 35:239245. CrossRef Medline

Reisert J, Matthews HR (2001) Response properties of isolated mouse olfactory receptor cells. J Physiol 530:113-122. CrossRef Medline

Sanhueza M, Schmachtenberg O, Bacigalupo J (2000) Excitation, inhibition, and suppression by odors in isolated toad and rat olfactory receptor neurons. Am J Physiol Cell Physiol 279:C31-C39. Medline

Saxton TK, Lyndon A, Little AC, Roberts SC (2008) Evidence that androsta- dienone, a putative human chemosignal, modulates women's attributions of men's attractiveness. Horm Behav 54:597-601. CrossRef Medline

Schild D, Restrepo D (1998) Transduction mechanisms in vertebrate olfactory receptor cells. Physiol Rev 78:429-466. Medline

Schmachtenberg O, Diaz J, Bacigalupo J (2003) NO activates the olfactory cyclic nucleotide-gated conductance independent from cGMP in isolated rat olfactory receptor neurons. Brain Res 980:146-150. CrossRef Medline

Spehr M, Kelliher KR, Li XH, Boehm T, Leinders-Zufall T, Zufall F (2006a) Essential role of the main olfactory system in social recognition of major histocompatibility complex peptide ligands. J Neurosci 26:1961-1970. CrossRef Medline

Spehr M, Spehr J, Ukhanov K, Kelliher KR, Leinders-Zufall T, Zufall F (2006b) Parallel processing of social signals by the mammalian main and accessory olfactory systems. Cell Mol Life Sci 63:1476-1484. CrossRef Medline

Stephan AB, Shum EY, Hirsh S, Cygnar KD, Reisert J, Zhao H (2009) ANO2 is the cilial calcium-activated chloride channel that may mediate olfactory amplification. Proc Natl Acad Sci U S A 106:11776-11781. CrossRef Medline

Stöhr H, Heisig JB, Benz PM, Schöberl S, Milenkovic VM, Strauss O, Aartsen WM, Wijnholds J, Weber BH, Schulz HL (2009) TMEM16B, a novel protein with calcium-dependent chloride channel activity, associates with a presynaptic protein complex in photoreceptor terminals. J Neurosci 29:6809-6818. CrossRef Medline

Teicher MH, Stewart WB, Kauer JS, Shepherd GM (1980) Suckling pheromone stimulation of a modified glomerular region in the developing rat olfactory bulb revealed by the 2-deoxyglucose method. Brain Res 194: 530-535. CrossRef Medline

Thompson JA, Salcedo E, Restrepo D, Finger TE (2012) Second-order input to the medial amygdala from olfactory sensory neurons expressing the transduction channel TRPM5. J Comp Neurol 520:1819-1830. CrossRef Medline

Tirindelli R, Dibattista M, Pifferi S, Menini A (2009) From pheromones to behavior. Physiol Rev 89:921-956. CrossRef Medline

Trotier D (2011) Vomeronasal organ and human pheromones. Eur Ann Otorhinolaryngol Head Neck Dis 128:184-190. CrossRef Medline

Wang Z, Storm DR (2011) Maternal behavior is impaired in female mice lacking type 3 adenylyl cyclase. Neuropsychopharmacology 36:772-781. CrossRef Medline

Wang Z, Balet Sindreu C, Li V, Nudelman A, Chan GC, Storm DR (2006) Pheromone detection in male mice depends on signaling through the type 3 adenylyl cyclase in the main olfactory epithelium. J Neurosci 26:73757379. CrossRef Medline

Wang Z, Nudelman A, Storm DR (2007) Are pheromones detected through the main olfactory epithelium? Mol Neurobiol 35:317-323. CrossRef Medline

Wyart C, Webster WW, Chen JH, Wilson SR, McClary A, Khan RM, Sobel N (2007) Smelling a single component of male sweat alters levels of cortisol in women. J Neurosci 27:1261-1265. CrossRef Medline

Wysocki CJ, Preti G (2004) Facts, fallacies, fears, and frustrations with human pheromones. Anat Rec A Discov Mol Cell Evol Biol 281:1201-1211. CrossRef Medline

Zufall F, Leinders-Zufall T (2007) Mammalian pheromone sensing. Curr Opin Neurobiol 17:483-489. CrossRef Medline 